An An Asian Journal of Soil Science

\title{
A Case Study
}

DOI : 10.15740/HAS/AJSS/13.1/80-86

\section{Soil quality concepts and assessment}

\author{
D. G. Padekar, S. U. Mokhale, S. N. Gawande and P. D. Peshattiwar
}

MEMBERS OF RESEARCH FORUM:

Corresponding author :

D.G. Padekar, Department of Soil Science and Agricultural Chemistry, Shri Shivaji College of Agriculture, Amravati (M.S.) India

Email: dgpadekar@gmail.com

Co-authors :

S. U. Mokhale, S. N. Gawande and P. D. Peshattiwar, Shri Shivaji College of Agriculture, Amravati (M.S.) India
Received : 10.04.2018; Accepted : 30.05.2018

\section{Summary}

Soil quality has become an internationally accepted science based tool for advancing the assessment, education and understanding of soil resources. Soil quality assessment is important for measuring changes in soil properties over time that helps to define effective management strategies, soil quality cannot be measured directly and there are different indicators (approaches) that can be used to quantify soil quality. These indicators signal desirable or undesirable changes in land and vegetation management that have occurred or may occurs in the future. Finally, various soil quality indexing approaches are available, that can be applied to deserve a range of critical test values within which soil quality and soil health accounts can be defined.

Key words : Soil quality, Concepts, Data set, Parameters, Soil quality assessment

How to cite this article : Padekar, D.G., Mokhale, S.U., Gawande, S.N. and Peshattiwar, P.D. (2018). Soil quality concepts and assessment. Asian J. Soil Sci., 13 (1) : 80-86 : DOI : 10.15740/HAS/AJSS/ 13.1/80-86. Copyright@ 2018: Hind Agri-Horticultural Society. 